\title{
Semi-scale Production of PHAs from Waste Frying Oil by Pseudomonas fluorescens $\mathbf{S 4 8}$
}

\author{
Rawia F. Gamal, Hemmat M. Abd El-Hady, Taha A. \\ Khodair, Enas A. Hassan, T. S. El-Tayeb and Khadiga A. \\ Abotaleb \\ Department of Agricultural Microbiology, Faculty of Agriculture, Ain \\ Shams University, Shoubra El-Kheima, Cairo, Egypt.
}

\begin{abstract}
THE PRESENT study aimed at developing a strategy to improve the production of polyhydroxyalkanoates (PHAs) by Pseudomonas fluorescens S48 using waste frying oil (WFO) as the sole carbon source. Several cultivations were set up to steadily improve nutrients supply to attain high cell density and high biopolymer productivity. The production of PHAs was examined in a 141 bioreactor as onestage batch, two-stage batch, and high-cell-density fed-batch cultures. The highest value of polymer content in one-stage bioreactor was obtained after $60 \mathrm{~h}(33.7 \%)$. Whereas, the two-stage batch culture increased the polymer content to $50.1 \%$ after $54 \mathrm{~h}$. High-cell-density $(0.64 \mathrm{~g} / \mathrm{l})$ at continuous feeding rate $0.55 \mathrm{ml} / \mathrm{l} / \mathrm{h}$ of WFO recorded the highest polymer content after $54 \mathrm{~h}(55.34 \%)$. Semi-scale application (10 1 working volume) increased the polymer content in one-stage batch, two-stage batch and high cell density fed-batch cultures by about $12.3 \%, 5.8 \%$ and $11.3 \%$, respectively, as compared with that obtained previously by the authors in 21 fermentation culture. Six different methods for biopolymer extraction were done to investigate their efficiency for optimum polymer recovery. The maximum efficiency of solvent recovery of PHAs was attained by chloroformhypochlorite dispersion extraction. Gas chromatography (GC) analysis of biopolymer produced by Pseudomonas fluorescens S48 indicated that it solely composed of 3-hydroxybutyric acid (98.7\%). A bioplastic film was prepared from the obtained PHB. The nucleotide sequence of the 16S rRNA gene of the studied isolate showed $98-99 \%$ similarity with Pseudomonas spp. particularly the Egyptian strain named Ps. fluorescens EG 639838.
\end{abstract}

Keywords: Pseudomonas fluorescens S48, Polyhydroxyalkanoates, Two-stage batch, High-cell-density fed batch, Bioreactor, Recovery.

Plastic materials have become an integral part of contemporary life because of many desirable properties including durability and resistance to degradation. The non-degradable plastics accumulate in the environment with an increasing rate. Recently, the problems concerning the global environment and solid waste

Cotact authors e-mails : rawiagamal123@yahoo.com (Rawia F. Gamal), hemmatabdelhady @ yahoo.com (Hemmat M. Abd El-Hady), enasath@hotmail.com (Enas A. Hassan), tarekeltayeb@yahoo.com (Tarek S.El-Tayeb), khadigaaboutaleb@ymail.com (Khadiga A. Aboutaleb). 
management have created much interest in the development of biodegradable plastics, which must still retain the desired physical and chemical properties of conventional synthetic plastics. One of the biodegradable plastic materials under development includes polyhydroxyalkanoates (PHAs) (Slater et al., 1998). However, one of the problems facing the development of biodegradable polymers as substitutes for conventional plastics is their high price compared with petrochemical derived plastics. Therefore, many efforts have been made to reach low-cost PHA production processes (Braunegg et al., 2007). Different potent strains, which grow to high-cell-density in cheap cultivation media and accumulating high PHA content via cost-efficient fermentation process and enabling easy recovery methods as well, were described in numerous investigations and patented processes (Kinoshita et al., 2005). Since one of the main obstacles that hinder an economic feasible production of PHA is the cost of carbon substrate ( $25 \%$ to $28 \%$ of total production cost). However, the abundance of inexpensive waste materials from agriculture, industry or agro-industrial such as waste frying oil present them as an alternative cheap substrates for microbial fermentations, in particular for the production of microbial polyesters (Da Silva et al., 2009).

Either fed-batch or continuous cultivation techniques can be used for the production of PHA with high productivity. Fed-batch culture has been the most popular culture system to achieve a high cell density and PHB content (Kim et al., 1994; Lee \& Yoo, 1994; Kim et al., 2003 and Valappil et al., 2007). In this system, it is essential to maintain optimal concentration of nutrients during fermentation. This can be achieved by using various feeding strategies (Wang \& Lee, 1997; Lee et al., 1997; Abdel Hafez et al., 2009 and Lopez-Cuellar et al., 2011).

In view of these facts, the current investigation is aimed to study the semiscale production of PHAs from waste frying oil using different fermentation techniques as batch and two-stage batch and high-cell-density fed-batch cultures in 141 bioreactor as well as using different methods for PHAs recovery.

\section{Materials and Methods}

\section{Microorganism and culture conditions}

Pseudomonas fluorescens $\mathrm{S} 48$ was used in this investigation for accumulating PHAs from waste frying oil (WFO). This bacterium was previously identified based on their microscopic, morphological and biochemical characters by Gamal et al. (2011). The bacterial culture was maintained by transferring at regular intervals on nutrient agar slants. Slants were kept at $4^{\circ} \mathrm{C}$ until used. For PHAs production, the bacterium was grown in basal medium modified by Gamal et al. (2012) called productive medium containing (g/l): $\left(\mathrm{NH}_{4}\right)_{2} \mathrm{SO}_{4}$ 1.0, $\mathrm{KH}_{2} \mathrm{PO}_{4}$ 1.5, $\mathrm{Na}_{2} \mathrm{HPO}_{4} \cdot 12 \mathrm{H}_{2} \mathrm{O}$ 9.0, $\mathrm{MgSO}_{4} .7 \mathrm{H}_{2} \mathrm{O} \quad 0.2,1 \mathrm{ml}$ of trace elements solution $\left(\mathrm{FeSO}_{4} .7 \mathrm{H}_{2} \mathrm{O} \quad 10, \mathrm{ZnSO}_{4} .7 \mathrm{H}_{2} \mathrm{O} \quad 2.25, \mathrm{CuSO}_{4} .5 \mathrm{H}_{2} \mathrm{O} \quad 1.0, \mathrm{MnSO}_{4} .4 \mathrm{H}_{2} \mathrm{O} \quad 0.5\right.$, $\mathrm{CaCl}_{2} .2 \mathrm{H}_{2} \mathrm{O} 2.0, \mathrm{Na}_{2} \mathrm{~B}_{4} \mathrm{O}_{7} .10 \mathrm{H}_{2} \mathrm{O} 0.23,\left(\mathrm{NH}_{4}\right)_{6} \mathrm{Mo}_{7} \mathrm{O}_{24} 0.1$ and $\left.35 \% \mathrm{HCl} 10 \mathrm{ml}\right)$ supplemented by $10 \mathrm{ml}$ of waste frying oil (waste vegetable oil obtained from the deep-frying of eggplant) as a sole carbon source. The $\mathrm{pH}$ was adjusted to 7.0 before sterilization.

Egypt. J. Microbiol. 47 (2012) 
Cultivation was done in a Bioflo 3000 14-liter fermenter (New Brunswick Scientific Co., Inc. Edison, NJ 08818-4005 USA), with a working volume of 10 liter (24 cm inner diameter and $45 \mathrm{~cm}$ height) and a d/D value (relation of stirrer diameter to vessel diameter) of 0.286 was used for cultivation. The bioreactor was equipped with three stirrers, each containing six paddles and a Funda-foam mechanical destroyer. In addition, sterilizable probes were inserted into ports to measure dissolved oxygen, $\mathrm{pH}$ and temperature. The operation were controlled and recorded. Cultivation was carried out at $30^{\circ} \mathrm{C}$ and $350 \mathrm{mM} / \mathrm{l} / \mathrm{h}$ oxygen transfer rate obtained through powerful fermentation agitation motor and 6-blades Rushton impellers dissolve $20 \%$ air saturation in the medium, which was controlled by agitation at $500 \mathrm{rpm}$ and aeration rate $1 \mathrm{vvm}$. Unless otherwise stated, the $\mathrm{pH}$ of medium was adjusted at $7.0 \pm 0.1$ by the controlled addition of $\mathrm{NaOH}(5 \mathrm{~N})$ or $4 \mathrm{~N} \mathrm{HCl}$. The operations were controlled and recorded by a digital control unit (DCU) in combination with the software package. Samples of 10-20 $\mathrm{ml}$ were withdrawn from the culture fluid for analytical purposes.

\section{Bioreactor as a one-stage batch culture}

In this experiment the fermentation vessel (bioreactor) containing $9800 \mathrm{ml}$ productive medium without WFO was autoclaved at $121^{\circ} \mathrm{C}$ for $40 \mathrm{~min}$. WFO (1\%) was added after sterilization. The fermentation medium was inoculated with $1 \%$ standard inoculum of the bacterial strain. The standard inoculum was prepared in a conical flask $(250 \mathrm{ml})$ containing $100 \mathrm{ml}$ of nutrient broth medium inoculated with a loop of Ps. fluorescens S48 and incubated at $28-30^{\circ} \mathrm{C}$ with shaking $(200 \mathrm{rpm})$ for $24 \mathrm{~h}$ prior to inoculation $\left(5 \times 10^{8} \mathrm{cfu} / \mathrm{ml}\right)$.

The final working volume was 10 liter. Initial $\mathrm{pH}$ was adjusted to $7.0 \pm 0.1$ which was not controlled during the fermentation period. Temperature, dissolved $\mathrm{O}_{2}$ and speed of agitation were kept at $30^{\circ} \mathrm{C}, 20 \%$ of air saturation and $500 \mathrm{rpm}$, respectively, during cultivation.

During fermentation, samples $(10-20 \mathrm{ml})$ were withdrawn from the culture (fermentation vessel) periodically. The samples were centrifuged at $15000 \mathrm{x} g$ for 4 min at $4^{\circ} \mathrm{C}$. The sediment (biomass) was washed twice with distilled water, and then dried at $70^{\circ} \mathrm{C}$ to constant weight.

\section{Bioreactor as a two-stage batch culture}

The production of PHAs was carried out in two-stage cultivation. In the first stage, two sterile conical flasks $(1000 \mathrm{ml})$ each containing $400 \mathrm{ml}$ nutrient medium was inoculated with $10 \mathrm{ml}$ standard inoculum of the bacterial strain, then incubated at $30^{\circ} \mathrm{C}$ for $24 \mathrm{~h}$ on rotary shaker $(200 \mathrm{rpm})$ in order to get a luxurious growth. Then the culture fluid was centrifuged at $15000 \mathrm{x} g$ for $4 \min$ at $4{ }^{\circ} \mathrm{C}$ and the bacterial cells were collected and suspended in additional sterile productive medium to inoculate the bioreactor vessel to give a final working volume of 101 sterile productive medium. The cultivation conditions and microbiological determinations were done as mentioned before. 


\section{Bioreactor as high-cell-density fed-batch culture}

This experiment of fed-batch culture was constructed to study the effect of washed high-cell-densities $(0.64 \mathrm{~g} / \mathrm{l})$ of Ps. fluorescens $\mathrm{S} 48$ on PHAs production. WFO was fed continuously at $0.55 \mathrm{ml} / \mathrm{l} / \mathrm{h}$ during the first $18 \mathrm{~h}$ of cultivation (according to the obtained results from Gamal et al. (2012) for the semi-scale production. Samples $(10-20 \mathrm{ml})$ were taken from the growing culture periodically under aseptic conditions to determine the cell dry weight, PHAs produced and residual carbon.

In all cultivations, polymer in samples was generally precipitated and determined as dry weight and PHAs content was calculated as dry weight percent. The extraction of PHAs was implemented by the chloroform-sodium hypochlorite method (Hahn et al.,1994). The concentration of organic carbon was determined in supernatant according to Walinga et al. (1992). Polymer content (\%) and productivity (g/l/h) were calculated according to Lee \& Choi (1998) and Lee (1996), respectively. The parameters of polymer yield (\%), conversion coefficient $(\%)$ and specific production rate $\left(\mu_{\mathrm{p}}\right)\left(\mathrm{h}^{-1}\right)$ were calculated according to Ramadan et al. (1985). The following formulas were used to calculate these parameters:

PHAs content $(\%)=$ Polymer concentration $(\mathrm{g} / \mathrm{l}) /$ cell dry weight $(\mathrm{g} / \mathrm{l}) \mathrm{x} 100$.

PHAs productivity $(\mathrm{g} / \mathrm{l} / \mathrm{h})=$ Polymer concentration $(\mathrm{g} / \mathrm{l}) /$ fermentation time $(\mathrm{h})$.

Yield $(\%)=$ PHAs $(\mathrm{g} / \mathrm{l}) /$ initial carbon $(\mathrm{g} / \mathrm{l}) \times 100$

Conversion coefficient $(\%)=$ Polymer concentration $(\mathrm{g} / \mathrm{l}) / \mathrm{utilized}$ carbon $(\mathrm{g} / \mathrm{l}) \mathrm{X} 100$

Specific production rate $\left(\mu_{\mathrm{p}}\right)\left(\mathrm{h}^{-1}\right)=$

Ln polymer $(\mathrm{g} / \mathrm{l})$ at $(\mathrm{t})$ time - Ln polymer $(\mathrm{g} / \mathrm{l})$ at $\left(\mathrm{t}_{0}\right) / \mathrm{t}-\mathrm{t}_{0}$

PHAs recovery

Six different methods for bioplastic recovery were performed as the following:

Recovery by commercial sodium hypochlorite solution

A $1 \mathrm{~g}$ of lyophilized cells was resuspended in $50 \mathrm{ml}$ of commercial sodium hypochlorite solution (clorox). After $1 \mathrm{~h}$ at $37^{\circ} \mathrm{C}$ the lipid granules were centrifuged, washed with water, and then washed with acetone and alcohol. Finally, the polymer was dissolved by extraction with three small portions of boiling chloroform, the chloroform solution was filtered, and the filtrate was used for biopolymer assay (Law \& Slepecky, 1961).

Recovery with dispersions of a sodium hypochlorite and chloroform

A $1 \mathrm{~g}$ of freeze-dried cells was treated with a dispersion containing $50 \mathrm{ml}$ of chloroform and $50 \mathrm{ml}$ of a diluted sodium hypochlorite solution (3\% vol/vol). After the cells were treated at $30^{\circ} \mathrm{C}$ for $1 \mathrm{~h}$, the mixture was centrifuged at $4000 \mathrm{x}$ $g$ for $10 \mathrm{~min}$, which resulted in three separate phases. The upper phase was a hypochlorite solution, the middle phase contained non-PHB cell material and undisrupted cells, and the bottom phase was chloroform containing PHB. The upper phase was removed first with a pipette, and the middle phase was separated by filtration from the chloroform phase. Finally, bottom phase was chloroform containing PHB. PHB was recovered from the chloroform phase by nonsolvent

Egypt. J. Microbiol. 47 (2012) 
precipitation (mixture of methanol and water 7:3, vol/vol) five times the volume of chloroform and filtration (Hahn et al.,1994).

\section{Recovery by acetone and chloroform}

A $1 \mathrm{~g}$ of freeze-dried cells powder was washed with hot acetone for $20 \mathrm{~min}$. After drying, the cell powder was mixed with 50 volumes of chloroform for $48 \mathrm{~h}$ at $30^{\circ} \mathrm{C}$. The clear polymer solution was recovered by centrifugation to remove the majority of the non-PHB cell material; this was followed by polishing filtration. Finally, pure biopolymer was obtained by nonsolvent precipitation (five times the volume of chloroform) and filtration. The nonsolvent used was a mixture of methanol and water 7:3 (vol/vol) (Hahn et al., 1995).

\section{Recovery by sodium hypochlorite}

A sodium hypochlorite solution was diluted with distilled water to give concentration $3 \%$ (vol/vol). A $1 \mathrm{~g}$ of lyophilized cells was mixed with $100 \mathrm{ml}$ of hypochlorite solution for $1 \mathrm{~h}$ at $30^{\circ} \mathrm{C}$. Biopolymer granules were separated from the aqueous fraction containing cell debris by centrifugation. The Polymer recovered was rinsed with distilled water, centrifuged again, and then rinsed with acetone (Hahn et al., 1995).

\section{Recovery by using chloroform}

A $1 \mathrm{~g}$ of lyophilized cells was ground in a mortar and the resulting powder was extracted with $50 \mathrm{ml}$ of chloroform for $4 \mathrm{~h}$ at $50^{\circ} \mathrm{C}$. The PHA-containing chloroform phase was concentrated and extracted once with water to remove residual solid particles. The organic phase was evaporated to dryness and the resulting crude extract preserved for further analyses. Purified PHAs were obtained by repeated precipitations in 10 volumes of cold methanol (Simon-Colin et al., 2008).

Recovery by sodium dodecyl sulfate (SDS)

A $1 \mathrm{~g}$ of lyophilized cells treated with $10 \% \mathrm{SDS}$ at $100^{\circ} \mathrm{C}$ for $20 \mathrm{~min}$. After centrifugation, the pellets were washed, dried and extracted with chloroform at $60^{\circ} \mathrm{C}$ for $1 \mathrm{~h}$. The non-PHB cell matter was removed by filtration and the dissolved $\mathrm{PHB}$ was separated from chloroform by evaporation, washed twice with methanol, filtered out and dried at $60-70^{\circ} \mathrm{C}$ (Jiang et al., 2008).

\section{GC analysis of biopolymer composition}

Composition of PHA was determined by GC as described by Mumtaz et al. (2009).

\section{Preparation of a biopolymer film}

Totally $250 \mathrm{mg}$ of PHB was dissolved in $28 \mathrm{ml}$ chloroform. The solution was evenly distributed into 5 petri dishes. The dishes were maintained at $30^{\circ} \mathrm{C}$ to allow complete evaporation of chloroform. The evaporation of solvent resulted in formation of PHB films in the petri dishes. Vacuum drying was further applied to completely remove any possible solvent remained in the films (Kai et al., 2003). 
16S rRNA gene sequence analysis

The studied bacteria were grown in nutrient broth on a rotary shaker (120 $\mathrm{rpm}$ ) at $20^{\circ} \mathrm{C}$ for $24 \mathrm{~h}$. Bacterial Genomic DNA Mini-Prep Kit (Axygen cat. No. V110440-05) was used to isolate DNA as advised by the manufacturer. The universal 16S primers used were: F1 5' AGAGTTT(G/C)ATCCTGGCTCAG 3' R1 5' ACGG(A/C)TACCTTGTTACGACTT 3'.

Primers were checked for specificity using the PROBE CHECK function of the Ribosomal Database and the BLAST search facility at the National Center for Biotechnology Information. DNA amplification was conducted on pure 2 to $3 \mu \mathrm{l}$ DNA sample with about $150 \mathrm{ng}$ of DNA per $1 \mu \mathrm{l}$ of sample in a perkin Elmer 2400 (Norwalk, CT) thermocycler. The F1 and R1 primers amplifying the PCR reactions were added with a final volume of $100 \mu \mathrm{l}$ with $0.2 \mu \mathrm{M}$ of each primer, $2.0 \mathrm{mM} \mathrm{MgCl} 2,200 \mu \mathrm{M}$ dNTPs and 2.5 units of Maxima ${ }^{\circledR}$ Hot start Taq DNA Polymerase (Fermentas, www.fermentas.com) mixed in the 1X PCR buffer. DNA was amplified over 35 cycles of denaturation for $1 \mathrm{~min}$ at $94^{\circ} \mathrm{C}$, annealing at $55^{\circ} \mathrm{C}$ for $1.5 \mathrm{~min}$ and extension at $72^{\circ} \mathrm{C}$ for $2 \mathrm{~min}$. After the last cycle, DNA was extended at $72^{\circ} \mathrm{C}$ for $10 \mathrm{~min}$. Amplification was confirmed by analyzing $5 \mu \mathrm{l}$ of PCR reaction mixture on $1 \%$ agarose gel (Promega). The resulting PCR products sizes were ranged from 1450 to $1500 \mathrm{bp}$.

The PCR-product was purified using QIAquik PCR Purification Kit (Qiagen), and sequenced using automatic ABI 310 DNA Sequencer, Big Dye Terminator Cycle Sequencing Ready Reaction Kit, Perkin Elmer. The sequencing was performed in two directions using the previously described primers (Lane et al., 1985 and Lane, 1991). Sequencing data was analyzed by two different computer alignment programs, DNAStar (DNASTAR, Inc., USA) and Sequence Navigator (Perkin, Corp., USA).

\section{Determination of phylogenetic relationships}

The BLAST database (Altschul et al., 1997) of National Center for Biotechnology Information was used to compare resolved sequence of the Ps. fluorescensS48 with known 16S rDNA sequences. Determination of phylogenetic relationships was analyzed by the program Phylogenetic Analysis megAlign of DNAstar version 7.0. The robustness of the internal branches of the trees was estimated by bootstrap analyses using 1000 replications in a heuristic search with random stepwise addition (111 replications) (Swofford, 1993). Bootstrap majority-rule $(>50 \%)$ consensus trees were obtained.

Statistical analysis

The collected data were statistically analyzed using IBM ${ }^{\circledR}$ SPSS $^{\circledR}$ Statistics software (2011). 


\section{Results and Discussion}

Semi-scale production of PHAs

The successful production of PHAs in both shaken flasks (Gamal et al., 2011) and 21 laboratory fermentor (Gamal et al., 2012) cultures generate the trials of semi-scale production of PHAs in 101 laboratory fermentor cultures (as working volume). Different fermentation techniques were applied in order to increase the PHAs yield using WFO as the sole carbon source.

\section{One-stage batch culture}

In batch culture, the cell mass increased gradually leading to record the maximum values of cell dry weight and polymer concentration $(2.93$ and $0.92 \mathrm{~g} / \mathrm{l}$, respectively) after $72 \mathrm{~h}$ of cultivation. Whereas, the maximum PHAs content $(33.7 \%)$ was obtained after $60 \mathrm{~h}$ fermentation period. The corresponding figures of polymer productivity and residual carbon were $0.015 \mathrm{~g} / \mathrm{l} / \mathrm{h}$ and $1.62 \mathrm{~g} / \mathrm{l}$, respectively. The highest values of PHAs yield was $12.11 \%$, obtained after $72 \mathrm{~h}$. Whereas, the highest conversion coefficient and specific production rate of PHAs were recorded after 60 and $24 \mathrm{~h}$ fermentation period $\left(15.22 \%\right.$ and $0.130 \mathrm{~h}^{-1}$, respectively) (see Table 1).

TABLE 1. Semi-scale production of PHAs by Ps. fluorescens $\mathrm{S48}$ on productive medium containing WFO as carbon source throughout $72 \mathrm{~h}$ at $30^{\circ} \mathrm{C}$ using bioreactor as a one-stage batch culture.

\begin{tabular}{|c|c|c|c|c|c|c|c|c|}
\hline $\begin{array}{c}\text { Time } \\
(\mathbf{h})\end{array}$ & $\begin{array}{c}\text { Cell dry } \\
\text { weight } \\
(\mathbf{g} / \mathbf{l})\end{array}$ & $\begin{array}{c}\text { Residual } \\
\text { carbon } \\
(\mathbf{g} / \mathbf{l})\end{array}$ & $\begin{array}{c}\text { PHAs } \\
\text { concentration } \\
(\mathbf{g} / \mathbf{l})\end{array}$ & $\begin{array}{c}\text { PHAs } \\
\text { content } \\
(\boldsymbol{\%})\end{array}$ & $\begin{array}{c}\text { PHAs } \\
\text { productivity } \\
(\mathbf{g} / / \mathbf{h})\end{array}$ & $\begin{array}{c}\text { Specific } \\
(\%)\end{array}$ & $\begin{array}{c}\text { Yield }(\mathbf{Y}) \\
\text { production rate } \\
\left(\boldsymbol{\mu}_{\mathbf{p}}\right) \\
\left(\mathbf{h}^{-1}\right)\end{array}$ & $\begin{array}{c}\text { Conversion } \\
\text { coefficient }(\mathbf{C C}) \\
(\boldsymbol{\%})\end{array}$ \\
\hline 0 & $0.15^{\mathrm{j}}$ & $7.60^{\mathrm{a}}$ & $0.00^{\mathrm{i}}$ & $0.00^{\mathrm{i}}$ & $0.000^{\mathrm{g}}$ & $0.00^{\mathrm{i}}$ & $0.000^{\mathrm{h}}$ & $0.00^{\mathrm{i}}$ \\
\hline 6 & $0.17^{\mathrm{i}}$ & $7.04^{\mathrm{b}}$ & $0.00^{\mathrm{i}}$ & $0.00^{\mathrm{i}}$ & $0.000^{\mathrm{g}}$ & $0.00^{\mathrm{i}}$ & $0.000^{\mathrm{h}}$ & $0.00^{\mathrm{i}}$ \\
\hline 12 & $0.25^{\mathrm{h}}$ & $6.08^{\mathrm{c}}$ & $0.04^{\mathrm{h}}$ & $16.00^{\mathrm{h}}$ & $0.003^{\mathrm{f}}$ & $0.53^{\mathrm{h}}$ & $0.000^{\mathrm{h}}$ & $2.63^{\mathrm{h}}$ \\
\hline 24 & $1.15^{\mathrm{g}}$ & $4.47^{\mathrm{d}}$ & $0.19^{\mathrm{g}}$ & $16.52^{\mathrm{g}}$ & $0.008^{\mathrm{e}}$ & $2.50^{\mathrm{g}}$ & $0.130^{\mathrm{a}}$ & $6.07^{\mathrm{g}}$ \\
\hline 30 & $1.38^{\mathrm{f}}$ & $3.62^{\mathrm{e}}$ & $0.31^{\mathrm{f}}$ & $22.46^{\mathrm{f}}$ & $0.010^{\mathrm{d}}$ & $4.08^{\mathrm{f}}$ & $0.114^{\mathrm{b}}$ & $7.79^{\mathrm{f}}$ \\
\hline 36 & $1.56^{\mathrm{e}}$ & $3.15^{\mathrm{f}}$ & $0.45^{\mathrm{e}}$ & $28.48^{\mathrm{e}}$ & $0.013^{\mathrm{b}}$ & $5.92^{\mathrm{e}}$ & $0.104^{\mathrm{c}}$ & $10.11^{\mathrm{e}}$ \\
\hline 48 & $1.99^{\mathrm{d}}$ & $2.62^{\mathrm{g}}$ & $0.59^{\mathrm{d}}$ & $29.65^{\mathrm{d}}$ & $0.012^{\mathrm{c}}$ & $7.76^{\mathrm{d}}$ & $0.075^{\mathrm{d}}$ & $11.85^{\mathrm{d}}$ \\
\hline 54 & $2.65^{\mathrm{c}}$ & $2.26^{\mathrm{h}}$ & $0.79^{\mathrm{c}}$ & $29.81^{\mathrm{c}}$ & $0.015^{\mathrm{a}}$ & $10.39^{\mathrm{c}}$ & $0.071^{\mathrm{e}}$ & $14.79^{\mathrm{c}}$ \\
\hline 60 & $2.74^{\mathrm{b}}$ & $1.62^{\mathrm{i}}$ & $0.91^{\mathrm{b}}$ & $33.70^{\mathrm{a}}$ & $0.015^{\mathrm{a}}$ & $11.97^{\mathrm{b}}$ & $0.065^{\mathrm{f}}$ & $15.22^{\mathrm{a}}$ \\
\hline 72 & $2.93^{\mathrm{a}}$ & $1.48^{\mathrm{j}}$ & $0.92^{\mathrm{a}}$ & $31.72^{\mathrm{b}}$ & $0.013^{\mathrm{b}}$ & $12.11^{\mathrm{a}}$ & $0.052^{\mathrm{g}}$ & $15.03^{\mathrm{b}}$ \\
\hline
\end{tabular}

Values in the same column followed by the same letter do not significantly differ from each other, according to Duncan's at $5 \%$ level.

\section{Two-stage batch culture}

Data presented in Tables 2 indicated that the cell dry weight of Ps. fluorescens S48 and PHAs concentration were increased gradually during the second stage of cultivation 
(production stage) to record the maximum values (5.42 and $2.60 \mathrm{~g} / \mathrm{l})$ after $72 \mathrm{~h}$ in productive medium containing $1 \% \mathrm{WFO}$ as the sole carbon source. The highest value of PHAs content $(50.10 \%$ ) was obtained after $54 \mathrm{~h}$, whereas, the highest values of yield and polymer productivity were obtained after 72 and $36 \mathrm{~h}(34.21 \%$ and $0.048 \mathrm{~g} / \mathrm{l} / \mathrm{h})$, respectively. The highest value of conversion coefficient of WFO carbon was $35.88 \%$ at $54 \mathrm{~h}$. These results are in line with those obtained by Kim et al. (1997) who performed a two-stage fed-batch cultivation using Ps. putida by supplying plant oils which resulted in good growth and could stimulate the biosynthesis of medium-chainlength polyhydroxy-alkanoates (MCL-PHA) efficiently.

TABLE 2. Semi-scale production of PHAs by Ps. fluorescens $\mathrm{S} 48$ on productive medium containing WFO as carbon source throughout $72 \mathrm{~h}$ at $30^{\circ} \mathrm{C}$ using bioreactor as a two-stage batch culture.

\begin{tabular}{|c|c|c|c|c|c|c|c|c|}
\hline $\begin{array}{c}\text { Time } \\
(\mathbf{h})\end{array}$ & $\begin{array}{c}\text { Cell } \\
\text { dry } \\
\text { weight } \\
(\mathbf{g} / \mathbf{l})\end{array}$ & $\begin{array}{c}\text { Residual } \\
\text { carbon } \\
(\mathbf{g} / \mathbf{l})\end{array}$ & $\begin{array}{c}\text { PHAs } \\
\text { concentration } \\
(\mathbf{g} / \mathbf{l})\end{array}$ & $\begin{array}{c}\text { PHAs } \\
\text { content } \\
(\boldsymbol{\%})\end{array}$ & $\begin{array}{c}\text { PHAs } \\
\text { productivity } \\
(\mathbf{g} / / \mathbf{l})\end{array}$ & $\begin{array}{c}\text { Yield } \\
(\mathbf{Y}) \\
(\%)\end{array}$ & $\begin{array}{c}\text { Specific } \\
\text { production } \\
\text { rate }\left(\boldsymbol{\mu}_{\mathbf{p}}\right) \\
\left(\mathbf{h}^{-1}\right)\end{array}$ & $\begin{array}{c}\text { Conversion } \\
\text { coefficient } \\
(\mathbf{C C}) \\
(\%)\end{array}$ \\
\hline 0 & $0.92^{\mathrm{j}}$ & $7.60^{\mathrm{a}}$ & $0.00^{\mathrm{i}}$ & $0.00^{\mathrm{i}}$ & $0.000^{\mathrm{h}}$ & $0.00^{\mathrm{i}}$ & $0.000^{\mathrm{h}}$ & $0.00^{\mathrm{i}}$ \\
\hline 6 & $1.32^{\mathrm{i}}$ & $7.07^{\mathrm{b}}$ & $0.00^{\mathrm{i}}$ & $0.00^{\mathrm{i}}$ & $0.000^{\mathrm{h}}$ & $0.00^{\mathrm{i}}$ & $0.000^{\mathrm{h}}$ & $0.00^{\mathrm{i}}$ \\
\hline 12 & $1.99^{\mathrm{h}}$ & $5.78^{\mathrm{c}}$ & $0.23^{\mathrm{h}}$ & $11.56^{\mathrm{h}}$ & $0.019^{\mathrm{g}}$ & $3.03^{\mathrm{h}}$ & $0.000^{\mathrm{h}}$ & $12.64^{\mathrm{h}}$ \\
\hline 24 & $2.94^{\mathrm{g}}$ & $5.40^{\mathrm{d}}$ & $0.92^{\mathrm{g}}$ & $31.29^{\mathrm{g}}$ & $0.038^{\mathrm{e}}$ & $12.11^{\mathrm{g}}$ & $0.116^{\mathrm{a}}$ & $41.82^{\mathrm{a}}$ \\
\hline 30 & $3.12^{\mathrm{f}}$ & $2.48^{\mathrm{e}}$ & $1.32^{\mathrm{f}}$ & $42.31^{\mathrm{f}}$ & $0.044^{\mathrm{c}}$ & $17.37^{\mathrm{f}}$ & $0.097^{\mathrm{b}}$ & $25.78^{\mathrm{g}}$ \\
\hline 36 & $3.64^{\mathrm{e}}$ & $1.68^{\mathrm{f}}$ & $1.72^{\mathrm{e}}$ & $47.25^{\mathrm{d}}$ & $0.048^{\mathrm{a}}$ & $22.63^{\mathrm{c}}$ & $0.084^{\mathrm{c}}$ & $29.05^{\mathrm{f}}$ \\
\hline 48 & $4.82^{\mathrm{d}}$ & $1.29^{\mathrm{g}}$ & $2.13^{\mathrm{d}}$ & $44.19^{\mathrm{e}}$ & $0.044^{\mathrm{c}}$ & $28.03^{\mathrm{d}}$ & $0.062^{\mathrm{d}}$ & $33.76^{\mathrm{e}}$ \\
\hline 54 & $4.97^{\mathrm{c}}$ & $0.66^{\mathrm{h}}$ & $2.49^{\mathrm{c}}$ & $50.10^{\mathrm{a}}$ & $0.046^{\mathrm{b}}$ & $32.76^{\mathrm{c}}$ & $0.057^{\mathrm{e}}$ & $35.88^{\mathrm{b}}$ \\
\hline 60 & $5.21^{\mathrm{b}}$ & $0.28^{\mathrm{i}}$ & $2.57^{\mathrm{b}}$ & $49.33^{\mathrm{b}}$ & $0.043^{\mathrm{d}}$ & $33.82^{\mathrm{b}}$ & $0.050^{\mathrm{f}}$ & $35.11^{\mathrm{c}}$ \\
\hline 72 & $5.42^{\mathrm{a}}$ & $0.07^{\mathrm{g}}$ & $2.60^{\mathrm{a}}$ & $47.97^{\mathrm{c}}$ & $0.036^{\mathrm{f}}$ & $34.21^{\mathrm{a}}$ & $0.040^{\mathrm{g}}$ & $34.53^{\mathrm{d}}$ \\
\hline
\end{tabular}

Values in the same column followed by the same letter do not significantly differ from each other, according to Duncan's at $5 \%$ level.

\section{High cell density fed-batch culture}

Using the previous improved results, further optimization was done using the same fed-batch technique with continuous WFO feeding at $0.55 \mathrm{ml} / \mathrm{l} / \mathrm{h}$ but with scaled up the volume of the bioreactor to 141 , aiming to reach a higher cell density and polymer productivity. Data given in Table 3 show that the maximum values of cell dry weight of Ps. fluorescens S48, PHAs concentration, content, yield and conversion coefficient were obtained after $54 \mathrm{~h}$ (4.21 g/l, $2.33 \mathrm{~g} / \mathrm{l}, 55.34 \%, 29.91 \%$ and $33.87 \%$, respectively), with initial cell dry weight of $0.64 \mathrm{~g} / \mathrm{l}$ and WFO continuous feeding rate at $0.55 \mathrm{ml} / \mathrm{l} / \mathrm{h}$. At this time, the polymer productivity was $0.043 \mathrm{~g} / \mathrm{l} / \mathrm{h}$. The highest specific production rate of PHAs was obtained during the first $12 \mathrm{~h}$ of fermentation period being $0.224 \mathrm{~h}^{-1}$. These results are in agreement with Yu (2007) who stated that fed-batch cultivation was more efficient than batch cultivation in terms of achieving high product and cell concentration of PHAs because the medium composition can be controlled. Therefore, high initial concentration of substrates fed can be avoided.

Egypt. J. Microbiol. 47 (2012) 
TABLE 3. Semi-scale production of PHAs by Ps. fluorescens $\mathrm{S} 48$ on productive medium containing WFO as carbon source throughout $72 \mathrm{~h}$ at $30^{\circ} \mathrm{C}$ using bioreactor as high-cell-density fed-batch culture with $0.64 \mathrm{~g} / \mathrm{l}$ cell density and continuous WFO feeding at $0.55 \mathrm{ml} / \mathrm{l} / \mathrm{h}$.

\begin{tabular}{|c|c|c|c|c|c|c|c|c|c|}
\hline $\begin{array}{c}\text { Time } \\
(\mathbf{h})\end{array}$ & $\begin{array}{c}\text { Added } \\
\text { WFO } \\
(\mathbf{m l} / \mathbf{l})\end{array}$ & $\begin{array}{c}\text { Added } \\
\text { carbon } \\
(\mathbf{g} / \mathbf{l})\end{array}$ & $\begin{array}{c}\text { Cell dry } \\
\text { weight } \\
(\mathbf{g} / \mathbf{l})\end{array}$ & $\begin{array}{c}\text { PHAs } \\
\text { concentration } \\
(\mathbf{g} / \mathbf{l})\end{array}$ & $\begin{array}{c}\text { PHAs } \\
\text { content } \\
(\boldsymbol{\%})\end{array}$ & $\begin{array}{c}\text { PHAs } \\
\text { productivity } \\
(\mathbf{g} / \mathbf{l} / \mathbf{h})\end{array}$ & $\begin{array}{c}\text { Yield } \\
(\mathbf{Y}) \\
(\boldsymbol{\%})\end{array}$ & $\begin{array}{c}\text { Specific } \\
\text { production } \\
\text { rate }\left(\boldsymbol{\mu}_{\mathbf{p}}\right) \\
\left(\mathbf{h}^{-1}\right)\end{array}$ & $\begin{array}{c}\text { Conversion } \\
\text { coefficient } \\
(\mathbf{C C}) \\
(\%)\end{array}$ \\
\hline 0 & $0.00^{\mathrm{d}}$ & $0.00^{\mathrm{d}}$ & $0.64^{\mathrm{j}}$ & $0.00^{\mathrm{j}}$ & $0.00^{\mathrm{j}}$ & $0.000^{\mathrm{h}}$ & $0.00^{\mathrm{j}}$ & $0.000^{\mathrm{i}}$ & $0.00^{\mathrm{j}}$ \\
\hline 6 & $3.30^{\mathrm{c}}$ & $2.57^{\mathrm{c}}$ & $1.01^{\mathrm{i}}$ & $0.06 \mathrm{i}$ & $5.94^{\mathrm{i}}$ & $0.010^{\mathrm{g}}$ & $2.33^{\mathrm{i}}$ & $0.000^{\mathrm{i}}$ & $3.85^{\mathrm{i}}$ \\
\hline 12 & $6.60^{\mathrm{b}}$ & $5.15^{\mathrm{b}}$ & $1.30^{\mathrm{h}}$ & $0.23^{\mathrm{h}}$ & $17.69^{\mathrm{h}}$ & $0.019^{\mathrm{f}}$ & $4.47^{\mathrm{h}}$ & $0.224^{\mathrm{a}}$ & $5.64^{\mathrm{h}}$ \\
\hline 24 & $9.99^{\mathrm{a}}$ & $7.79^{\mathrm{a}}$ & $1.98^{\mathrm{g}}$ & $0.58^{\mathrm{g}}$ & $29.29^{\mathrm{g}}$ & $0.024^{\mathrm{e}}$ & $7.45^{\mathrm{g}}$ & $0.126^{\mathrm{b}}$ & $12.66^{\mathrm{g}}$ \\
\hline 30 & $9.99^{\mathrm{a}}$ & $7.79^{\mathrm{a}}$ & $2.13^{\mathrm{f}}$ & $0.71^{\mathrm{f}}$ & $33.33^{\mathrm{f}}$ & $0.024^{\mathrm{e}}$ & $9.11^{\mathrm{f}}$ & $0.103^{\mathrm{c}}$ & $13.37^{\mathrm{f}}$ \\
\hline 36 & $9.99^{\mathrm{a}}$ & $7.79^{\mathrm{a}}$ & $2.42^{\mathrm{e}}$ & $0.97^{\mathrm{e}}$ & $39.98^{\mathrm{e}}$ & $0.027^{\mathrm{d}}$ & $12.45^{\mathrm{e}}$ & $0.093^{\mathrm{d}}$ & $15.88^{\mathrm{e}}$ \\
\hline 48 & $9.99^{\mathrm{a}}$ & $7.79^{\mathrm{a}}$ & $3.98^{\mathrm{c}}$ & $2.17^{\mathrm{c}}$ & $54.52^{\mathrm{c}}$ & $0.045^{\mathrm{a}}$ & $27.86^{\mathrm{c}}$ & $0.085^{\mathrm{e}}$ & $33.38^{\mathrm{b}}$ \\
\hline 54 & $9.99^{\mathrm{a}}$ & $7.79^{\mathrm{a}}$ & $4.21^{\mathrm{a}}$ & $2.33^{\mathrm{a}}$ & $55.34^{\mathrm{a}}$ & $0.043^{\mathrm{b}}$ & $29.91^{\mathrm{a}}$ & $0.076^{\mathrm{f}}$ & $33.87^{\mathrm{a}}$ \\
\hline 60 & $9.99^{\mathrm{a}}$ & $7.79^{\mathrm{a}}$ & $4.11^{\mathrm{b}}$ & $2.26^{\mathrm{b}}$ & $54.99^{\mathrm{b}}$ & $0.038^{\mathrm{c}}$ & $29.01^{\mathrm{b}}$ & $0.067^{\mathrm{g}}$ & $31.52^{\mathrm{c}}$ \\
\hline 72 & $9.99^{\mathrm{a}}$ & $7.79^{\mathrm{a}}$ & $3.32^{\mathrm{d}}$ & $1.39^{\mathrm{d}}$ & $41.87^{\mathrm{d}}$ & $0.019^{\mathrm{f}}$ & $17.84^{\mathrm{d}}$ & $0.048^{\mathrm{h}}$ & $18.41^{\mathrm{d}}$ \\
\hline
\end{tabular}

Values in the same column followed by the same letter do not significantly differ from each other, according to Duncan's at $5 \%$ level.

In the previous study fed-batch fermentation (bioreactor 31 containing 21 medium) (Gamal et al., 2012), a relatively high cell dry weight and high polymer content were achieved after a short incubation time $(48 \mathrm{~h})$. Both were higher by a factor of 2.4 and 4.14, respectively, than those recorded in shake flask experiments after $72 \mathrm{~h}$ (Gamal et al., 2011). Also, it could be noticed that the application of high cell density fed-batch culture in 101 fermentation medium (bioreactor 14 l) increased the PHAs content by about $64.21 \%$ and $10.46 \%$ than that obtained by one-stage batch and two-stage batch cultures (bioreactor containing 101 medium), respectively, as well as shortened the fermentation period by about $6 \mathrm{~h}$ comparing with batch culture. Also it could be stated that using the 101 fermentation culture led to increase the PHAs content of one-stage batch, two-stage batch and high cell density fed batch cultures about $12.3 \%, 5.8 \%$ and $11.3 \%$, respectively, than that obtained in 21 fermentation culture (Table 4). These results are in line with those obtained by Valappil et al. (2007), they stated that a simple glucose feeding strategy in 201 batch fermentation increased the polymer yield by $31 \%$ compared to the batch culture. Additionally, Riesenberg \& Guthke (1999) stated that high cell density cultivations represented an about 10-20 fold increase in growth in comparison to normal cell density growth. Problems encountered by high cell density cultivation are numerous, such as $\mathrm{PO}_{2}$ deficiency, by-product formation, and/or metabolic heat production. As a result of the growing industrial interest in high cell density, many attempts have been made to improve high cell density fermentations, such as improving potent strain, and/or applying different types of bioreactors and cultivation strategies.

Egypt. J. Microbiol. 47 (2012) 
TABLE 4. Comparative performance of PHAs production from some Egyptian raw materials by $\boldsymbol{P}$ s. fluorescens $\mathbf{S 4 8}$ via different fermentation strategies.

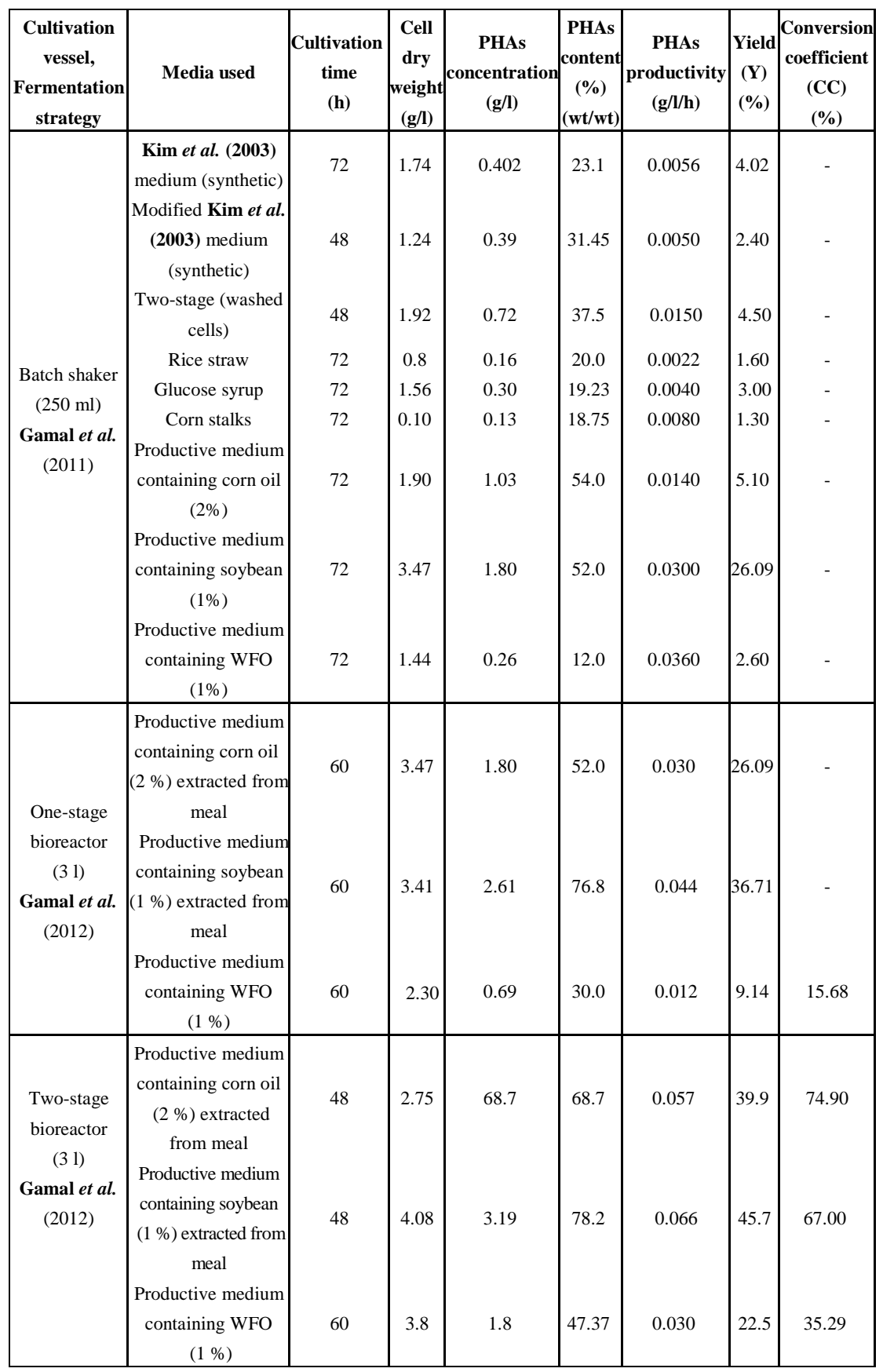

Egypt. J. Microbiol. 47 (2012) 
TABLE 4. Cont.

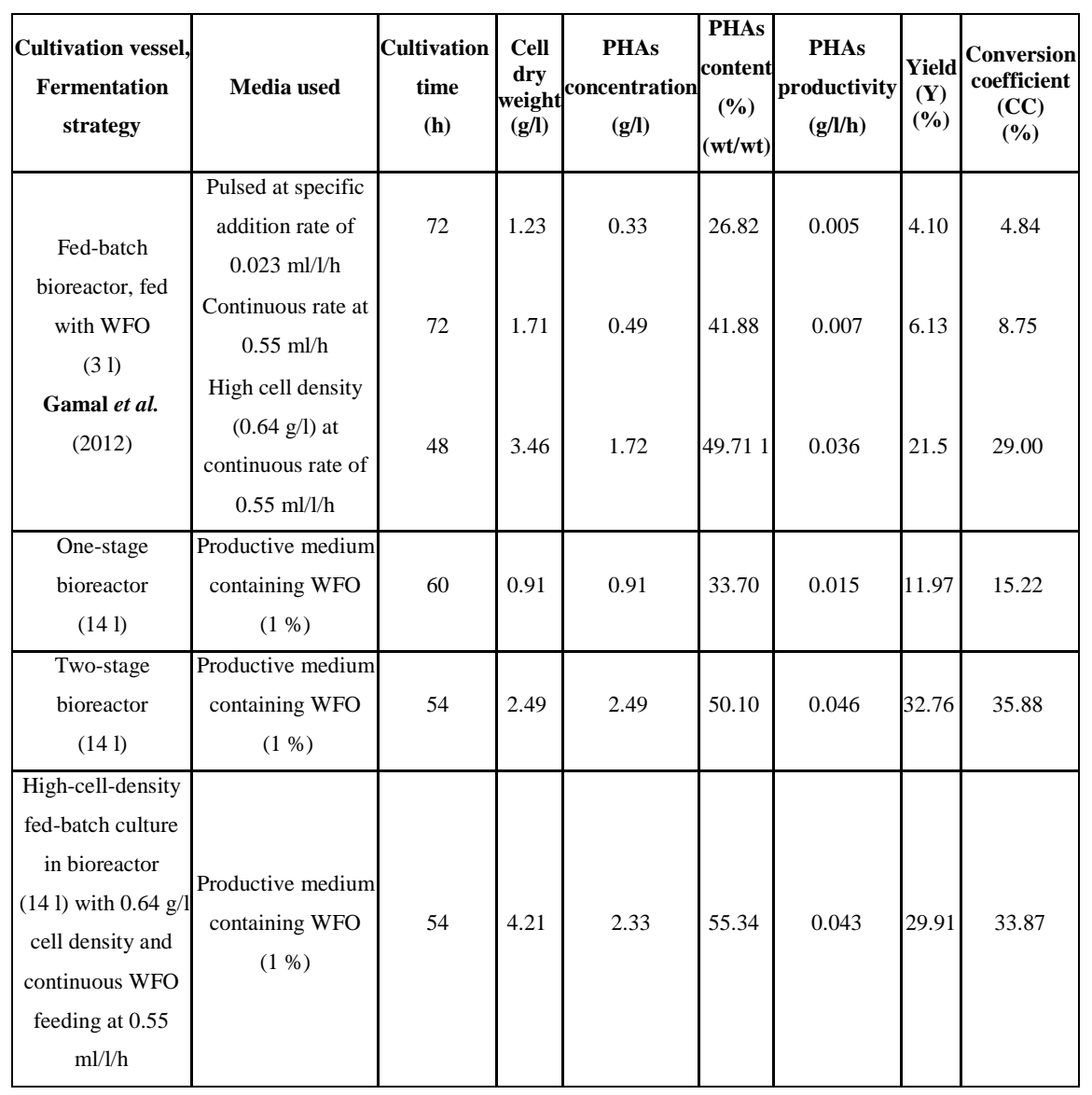

\section{PHAs recovery}

One of the most important prerequisites for an industrial strain for PHA production is how easy PHA can be recovered from non-PHA cell matter (Suriyamongkol et al., 2007). Although several new downstream processes for the extraction of PHAs have been reported as economically effective, such as the application of surfactants and the dispersions of hypochlorite solution and chloroform, solvent extraction methods are still regarded as an adequate way to gain intact polymer with high purity and recovery yield (Ramsay et al., 1990). The organic solvents were investigated to determine their efficiency to recover PHAs and how easy the separation of them from cells debris after extraction could be. Data illustrated in Fig. 1 show that the maximum efficiency of solvent recovery of PHA was attained by chloroform-hypochlorite dispersion extraction (method 2, 55\%) followed by that extracted with chloroform $60^{\circ} \mathrm{C}$ for $1 \mathrm{~h}$ after pretreatment the cells with $10 \% \mathrm{SDS}$ at $100^{\circ} \mathrm{C}$ for $20 \min (\operatorname{method} 6,53 \%)$. However, polymer recovery by hot acetone and chloroform (method 3 ) or sodium 
hypochlorite alone (method 4) gave the lowest PHAs content (40\% and $39 \%$, respectively). The corresponding figures of PHAs concentration were 2.3, 2.0, 1.5 and $1.42 \mathrm{~g} / \mathrm{l}$, respectively. There is still a need to develop and improve these extraction methods further to make the entire processes much simpler and cheaper.

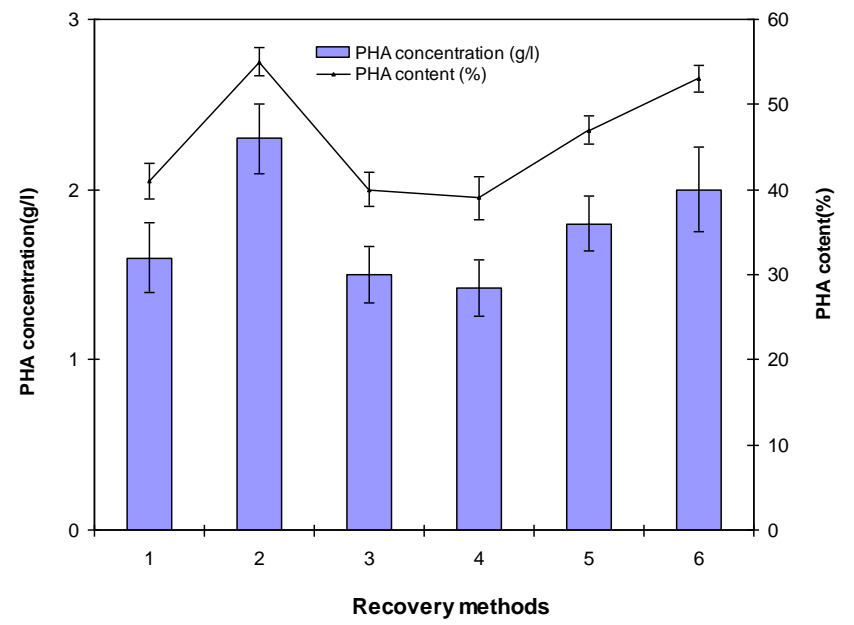

Fig.1. Efficacy of different recovery methods (1-6) on PHAs extraction from Ps. fluorescens $\mathbf{S 4 8 .}$ Recovery methods by:1) Commercial sodium hypochlorite solution. 2) Sodium hypochlorite and chloroform. 3) Acetone and chloroform. 4) Sodium hypochlorite. 5) Chloroform. 6) Sodium dodecyl sulfate. The Error bars represent standard deviation of the mean values of the results of three independent culture replicate.

Analysis of PHA by gas chromatography

Gas chromatography (GC) analysis revealed that polyhydroxyalkanoates (PHAs) produced from Ps. fluorescens S48 was solely composed of 3hydroxybutyric acid (98.7\%) (Fig. 2). Therefore, this feature made them highly competitive with polyethylene and petrochemical-derived plastics. The biodegradable biopolymer (PHB) are often preferred materials not only for environmental considerations, but also in medical application such as developing therapeutic devices, for tissue engineering and for slow release drug delivery systems (Nair \& Laurencin, 2007). Bioplastic film was prepared from the recovered PHA biopolymer which was solely composed of 3-hydroxybutyric acid (98.7\%) (Fig. 3).

\section{Phylogenetic analysis}

In case of genus Pseudomonas, nearly complete sequences have been determined for the PCR amplified 16S rRNA genes of about 21 species (Moore et al., 1999). In this report, we have further investigated the taxonomic position of the bacterial isolate Ps. fluorescens $\mathrm{S} 48$, which was proposed here to represent a species, upon sequencing most of the 16S rRNA gene, it was

Egypt. J. Microbiol. 47 (2012) 
discovered that the isolate Ps. fluorescens S48 shares the same identical sequence, which is nearly the complete 16S rRNA gene. The identity of this sequence to the closest Pseudomonads strains is about 98-99\%. Concerning the phylogenetic tree constructed in this study it was interesting to note that the isolate Ps. fluorescens S48 is so close to the Egyptian strain named EG 639838 (similarity level 99\% ) (Fig. 4). Based on phylogenetic study, the analysis of the $16 \mathrm{~S}$ rRNA gene sequences data for the isolate Ps. fluorescens share the same sequence, but slightly differ from other Pseudomonas species.

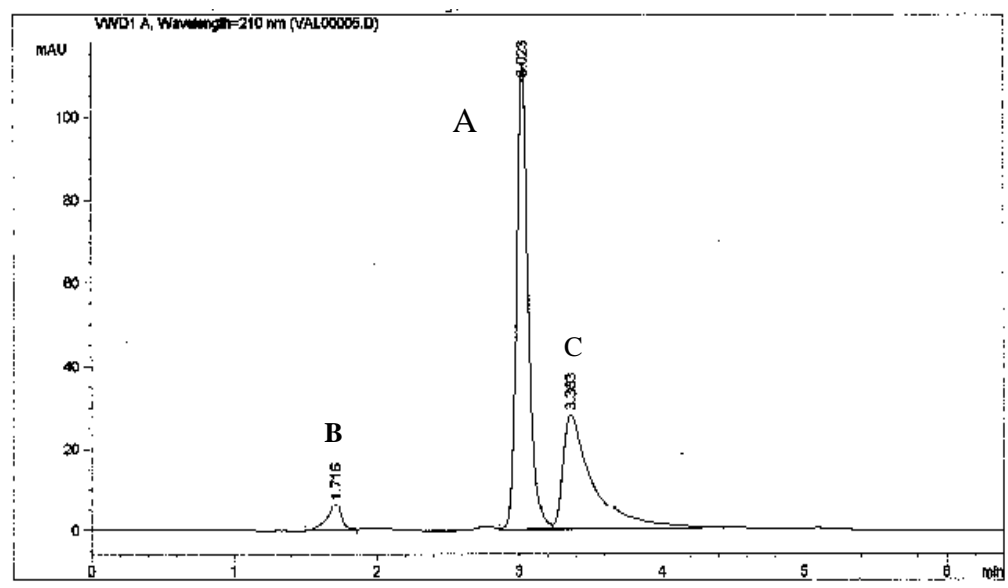

Retention time (min)

Fig. 2. Gas chromatography (GC) of 3HB-methyl ester indicating that the biopolymer produced by Ps. fluorescens S48 was solely composed of 3-hydroxybutyric acid (peak A), peaks $B$ and $C$ were not identified.

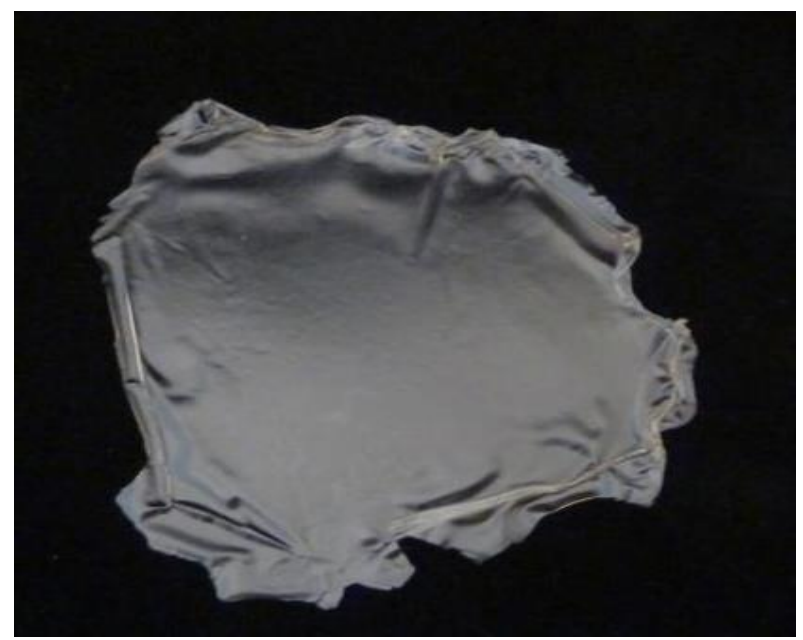

Fig. 3. Bioplastic film made of PHB produced by Ps. fluorescens S48 .

Egypt. J. Microbiol. 47 (2012) 


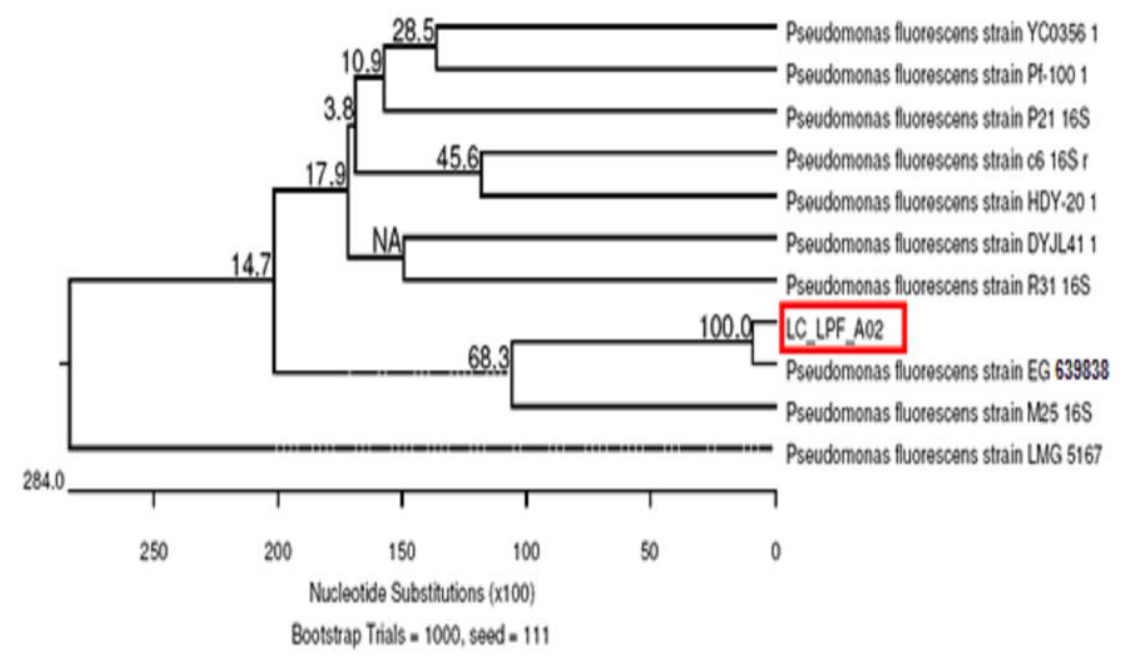

Fig. 4. Neighbor-joining tree showing the estimated phylogenetic relationships of the studied strain (shown in box) and other closely-related strains of the genus Pseudomonas based on comparative analysis of 16S rRNA gene sequences.

\section{Conclusions}

Pseudomonas fluorescens S48 when grew with waste cooking vegetable oils as a carbon source, the results indicated that PHB content and productivity were varied according to the applied feeding strategy in bioreactor. WFO submitted to different feeding strategies proved that the high-cell-density $(0.64 \mathrm{~g} / \mathrm{l})$ at continuous feeding rate $0.55 \mathrm{ml} / \mathrm{l} / \mathrm{h}$ of WFO increased the PHB content and the productivity by 1.64 and 2.9 fold, respectively in addition to minimize the incubation period by $6 \mathrm{~h}$ comparing with that in one-stage bioreactor . Chloroform-hypochlorite proved the high efficient in biopolymer recovery which led to prepare a bioplastic film contains $98.7 \%$ PHB.

Acknowledgment: The authors are pleased to acknowledge Science and Technology Development Fund (STDF) for financial support.

\section{References}

Abdel Hafez, A.M., Abdelhady, Hemmat M., El-Sayed, Azhar A. and Khodair, T.A. (2009) Fermentative production of polyhydroxybutyrate (PHB) by high cell density culture of $R$. eutropha and A. latus in pH-stat fed-batch culture. J. Biol. Chem. Environ. Sci. 4, 93-107. 
Altschul, S.F., Madden, T.L., Schaffer, A.A., Zhang, J., Zhang, Z., Miller, W. and Lipman, D.J. (1997) Gapped BLAST and PSIBLAST: a new generation of protein database search programs. Nucleic Acids Res. 25, 3389-3402.

Braunegg, G., Lefebvre, G. and Genser, K.F. (2007) Polyhydroxyalkanoates, biopolyesters from renewable resources: physiological and engineering aspects. $J$. Biotechnol. 65,127-161.

Da Silva, G.P., Mack, M. and Contiero, J. (2009) Glycerol: A promising and abundant carbon source for industrial microbiology. Biotechnol. Adv. 27, 30-39.

Gamal, Rawia, F., Abd El-hady, Hemmat M., Hassan, Enas A., El-Tayeb, T.S. and Aboutaleb, Khadiga A. (2011) Production of polyhydroxyalkanoate (PHAs) and copolymer $[\mathrm{P}(\mathrm{HB}-\mathrm{co}-\mathrm{HV})]$ by soil bacterial isolates in batch and two-stage batch cultures. Egypt. J. Microbiol. 46, 109-123.

Gamal, Rawia, F., Abd El-hady, Hemmat M., Hassan, Enas A., El-Tayeb, T.S. and Aboutaleb, Khadiga A. (2012) Production of PHAs from waste frying oil by Pseudomonas fluorescens S48 using different bioreactor feeding strategies. Egypt. J. Microbiol. 47, 1-5.

Hahn, S.K., Chang, Y.K., Kim, B.S. and Chang, H.N. (1994) Optimization of microbial poly (3-hydroxybutarate) recovery using dispersions of sodium hypochlorite solution and chloroform. Biotechnol. Bioeng. 44, 256-261.

Hahn, S.K., Chang, Y.K. and Lee, S.Y. (1995) Recovery and characterization of poly(3hydroxybutyric acid) synthesized in Alcaligenus eutrophus and Recombinant Escherichia coli. Appl. Environ. Microbial. 61, 34-39.

IBM $^{\circledR}$ SPSS $^{\circledR}$ Statistics (2011) Version 19.0, SPSS Inc., Chicago, Illinois.

Jiang, Y., Song, X., Gong, L., Li, P., Dai, C. and Shao, W. (2008) High poly ( $\beta$ hydroxybutyrate) production by Pseudomonas fluorescens A2a5 from inexpensive substrates. Enzyme Microb. Technol. 42, 167-172.

Kai, Z., Ying, D. and Guo-Qiang, Ch. (2003) Effects of surface morphology on the biocompatibility of polyhydroxyalkanoates. Biochem. Eng. J. 16, 115-123.

Kim, B.S., Lee, S.C., Lee, S.Y., Chang, H.N., Chang, Y.K. and Woo, S.I. (1994) Production of poly $\beta$ (3-hydroxybutyric acid) by fed-batch culture of Alcaligenes eutrophus with glucose concentration control. Biotechnol. Bioeng. 43, 892-898.

Kim, G.J., Lee, I.Y., Yoon, S.C., Shin, Y.C. and Park, Y.H. (1997) Enhanced yield and a high production of medium-chain-length poly(3-hydroxyalkanoates) in a two-step fed-batch cultivation of Pseudomonas putida by combined use of glucose and octanoate. Enzyme and Microb. Technol. 20, 500-505.

Kim, M., Cho, K.S., Ryu, H.W., Lee, E.G. and Chang, Y.K. (2003) Recovery of poly (3- hydroxybutyrate) from high cell density culture of Ralstonia eutropha by direct addition of sodium dodecyl sulfate. Biotechnol. Lett. 25, 55-59. 
Kinoshita, K., Yanagida, Y., Osakada, F., Ueda, Y., Narasimhan, K., Cearley, A., Yee, K. and Noda, I. (2005) Method for producing polyhydroxyalkanoates. US patent application US0239998.

Lane, D.J. (1991) 16S/23S rRNA sequencing. In: "Nucleic Acid Techniques in Bacterial Systematics", E. Stackebrandt and M. Goodfellow(Ed.), pp. 115-148. John Wiley \& Sons, Inc., New York, NY.

Lane, D.J., Pace, B.G., Olsen, J., Stahl, D.A., Sogin, M.L. and Pace, N.R. (1985) Rapid determination of $16 \mathrm{~S}$ ribosomal RNA sequences for phylogenetic analyses. Proc. Natl. Acad. Sci. USA. 82, 6955-6959.

Law, J.H. and Slepecky, R.A. (1961) Assay of poly $\beta$ hydroxybutyric acid. J. Bacteriol. $\mathbf{8 2}, 33-36$.

Lee, S.Y. (1996) Plastic bacteria. Progress and prospects for polyhydroxyalkanoate production in bacteria. Trends Biotechnol. 14, 431-438.

Lee, S.Y. and Choi., J. (1998) Polyhydroxyalkanoates biodegradable polymer. In: "Manual of Industrial Microbiology and Biotechnology" Demain, A.L. and Davies, J.E. (Ed.). ( $2^{\text {nd }}$ ed.), pp. $616-627$. ASM Press, Washington, D.C.

Lee, S.Y., Middelberg, A.P. and Lee, Y.K. (1997) Poly(hydro-xybutytrate) production from whey using recombinant Escherichia coli. Biotechnol. Lett. 19, 1033-1035.

Lee, Y.W. and Yoo, Y.J. (1994) High cell density culture of Alcaligenes eutrophus and poly- $\beta$-hydroxybutyrate production by optimization of medium compositions. $J$. Appl. Microbiol. Biotechnol. 22, 401-406.

Lopez-Cuellar, M.R., Alba-Flores, J., Gracida Rodrîguez, J.N. and Pérez-Guevara, F. (2011) Production of polyhydroxyalkanoates (PHAs) with canola oil as carbon source. Inter. J. Biol. Macromol. 48, 74-80.

Moore, E., Arnscheidt, A., Kruger, A., Stromple, C. and Mau, M. (1999) Simplified protocols for the preparation of genomic DNA from bacterial cultures. In: "Molecular Microbial Ecology Manual", Akkermans, A.D.L.; van Elsas, J.D.; de Bruijn, F.J. (Ed.), pp. 1-15. Dordrecht, The Netherlands: Kluwer Academic Press. 1.6.1.

Mumtaz, T.S., Abd-Aziz, N., Abdul Rahman, P., Yee, L., Shirai, Y. and Hassan, M.A. (2009) Fed-batch production of $\mathrm{P}(3 \mathrm{HB}-\mathrm{co}-3 \mathrm{HV})$ copolymer by Comamonas sp. EB 172 using mixed organic acids under dual nutrient limitation. Eur.J. Sci. Res. 33, 374-384.

Nair, L.S. and Laurencin, C.T. (2007) Biodegradable polymers as biomaterials. Prog. Polym. Sci. 32, 762-798.

Ramadan, E.M., El-Sawy, M., Gamal, Rawia F. and Abd El-hady, Hemmat M. (1985) Growth parameters of yeast grown on agricultural residues using shake flasks as a batch culture. Annals Agric. Sci., Fac. Agri., Ain Shams Univ., Cairo, Egypt, 30, 25-45.

Ramsay, B.A., Lomaliza, K., Chavarie, C., Dube, B., Bataille, P. and Ramsay, J.A. (1990) Production of Poly-( $\beta$-hydroxybutyric-co- $\beta$-hydroxyvaleric) acids. Appl. Environ. Microbiol. 56, 2093-2098.

Egypt. J. Microbiol. 47 (2012) 
Riesenberg, D. and Guthke, R. (1999) High-cell-density cultivation of microorganisms. Appl. Microbiol. Biotechnol. 51, 350-360.

Simon-Colin, C., Raguénès, G., Costa, B. and Guezennec, J. (2008) Biosynthesis of medium chain lengthpoly-3-hydroxyalkanoates by Pseudomonas guezennei from various carbon sources. React. Funct. Polym. 68, 1534-1541.

Slater, S., Houmiel, K.L., Tran, M., Mitsky, T.A., Taylor, N.B., Padgette, S.R. and Gruys, K.J. (1998) Multiple beta-ketothiolases mediate poly (beta-hydroxyalkanoate) copolymer synthesis in Ralstonia eutropha. J. Bacteriol. 180, 1979-1987.

Suriyamongkol, P.F., Weselake, R., Narine, S., Moloney, M. and Shah, S. (2007) Biotechnological approaches for the production of polyhydroxyalkanoates in microorganisms and plants. A review. Biotechnol. Adv. 25, 148-175.

Swofford, D.L. (1993) PAUP: Phylogenetic analysis using parsimony, version 3.1.1. Illinois Natural History Survey, Champaign.

Valappil, S.P., Misra, S.K., Boccaccini, A.R., Keshavarz, T., Bucke, C. and Roy, I. (2007) Large-scale production and efficient recovery of PHB with desirable material properties, from the newly characterized Bacillus cereus SPV. J. Biotechnol. 132, 251-258.

Walinga, I., Novozamsky, I. and Houba, V.J.G. (1992) Spectrophotometric determination carbon of organic in soil. Commun Soil Sci. Plant Anal. 23, 1935-1944.

Wang, F. and Lee, S.Y. (1997) Production of poly $\beta$ (3-hydroxybutyrate) by fed-batch culture of filamentation-suppressed recombinant Escherichia coli. Appl. Environ. Microbiol. 63, 4765-4769.

Yu, J. (2007) Microbial production of bioplastics from renewable resources. In: "Bioprocessing for Value-added Products from Renewable Resources". Yang, S. T. (Ed). pp.585-610. Elsevier BV., UK.

(Received 1/12/2011; accepted $1 / 2 / 2012$ ) 


\section{الأنتاج النصف صناعى لمركب البولي هيدروكسى الكونيت من

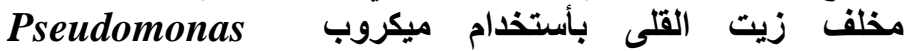 \\ fluorescens $\mathbf{S 4 8}$}

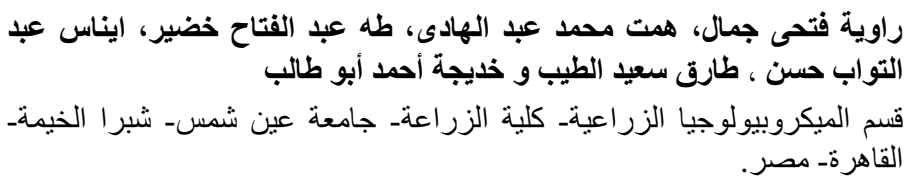

تهدف الدراسة إلى تحسين ظروف الأنتاج الكمى من البولى هيدروكسى الكونيت

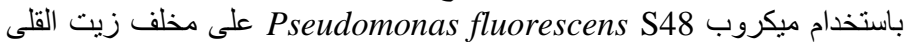

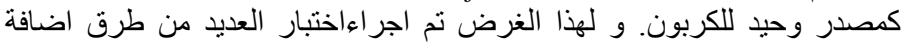

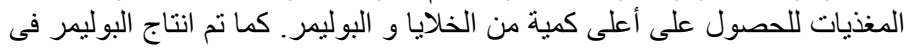

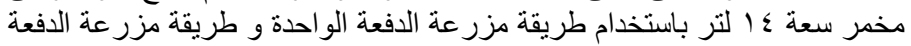

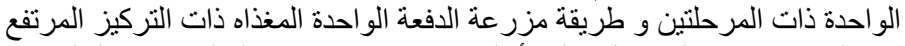

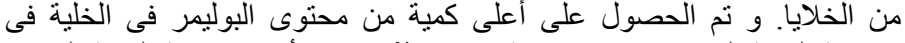

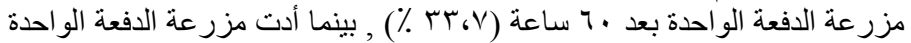

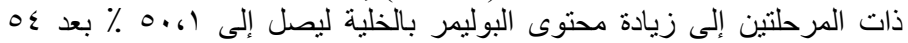

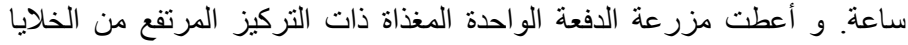

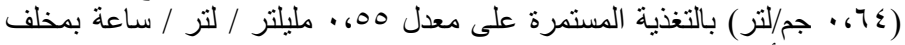

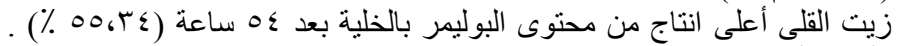

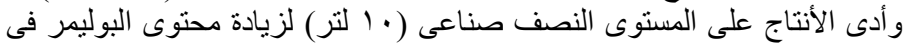

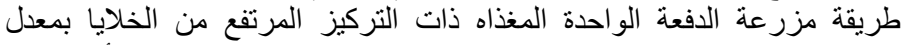

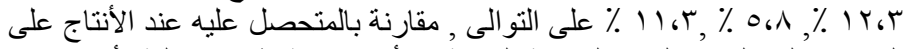

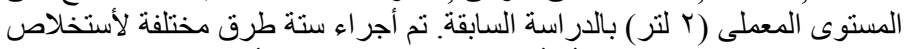

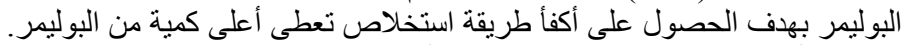

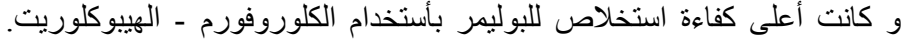

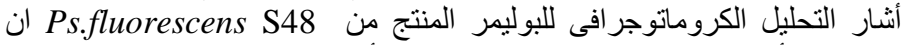

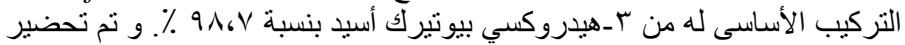

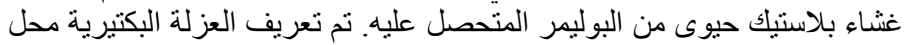

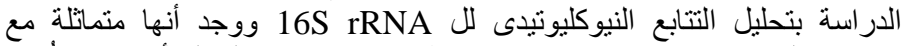

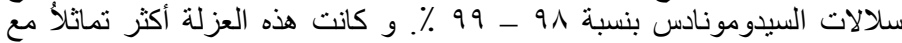

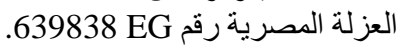

